\title{
FAR RIGHT POPULIST CHALLENGE IN EUROPE. ALTERNATIVE FOR GERMANY AND THE NATIONAL FRONT
}

\author{
Adina-Elena Cincu, PhD Student \\ National University of Political Studies and Public Administration \\ Bucharest/Romania \\ cincu_adina_elena@yahoo.com
}

\begin{abstract}
The answers offered by EU Member States in sensitive moments (the financial crisis of 2008, the refugees ' crisis, the terrorist attacks), have eroded European citizens' confidence in the Union's capacity to manage such surprising and unprecedented dynamics, while simultaneously deepening their perception of EU as a partially delegitimized supranational entity. Right-Wing populist parties have gradually increased their attractiveness by capitalizing on the frustration and disenfranchisement feelings perceived by European citizens. European populist parties promote the alternative of a direct opposition towards the system 's political correctness and against the perceived blockage of democratic debate, on their path toward gaining real effective political power.

I will start with a short introduction of a theoretical approach of far-right populism in Europe. Using a qualitative research method, defined by discourse analysis (speeches, statements), I will then illustrate the way the political programs of Alternative for Germany (AfD) and Le Pen`s National Front (FN) were thought and built in order to understand how these have led to an increase in the appeal of European populist parties. In the conclusions section I will evaluate the impact of these political alternative movements on the future of the European Union`s essence, on its main values and principles.
\end{abstract}


Key Words: European Union, far-right parties, immigration, nationalism, populism, sovereignty

\section{POPULISM - SHORT INTRODUCTION AND THEORETICAL APPROACH}

The European Union is going through a difficult period, which will mark its evolution. All the European values (democracy, human rights, tolerance) have been consolidated in time due to the growing solidarity among EU Member States. The 2008 financial crisis, followed by difficult economic consequences, the ascending level of homegrown Islamic-salafi terrorism coupled with the social, economic and even psychological impact of the refugees crisis, have fuelled growing frustration, perceptions of insecurity, uncertainty and fear in numerous European societies. Building on the growing frustration and disenchantment, far-right populism has won a fast path to the hearts and minds of some European citizens, illustrated by the fact that from the 1960s, until today, the support obtained by populist parties across Europe, in different election polls increased from $5.1 \%$ to $13.2 \%$. (Inglehart and Norris 2016)

Norbert Hofer, the far-right Freedom Party leader in Austria received a stunning $49 \%$ of the votes in the presidential elections in 2016, and even if Hofer was in the end defeated, his gradual strong support has illustrated the possibility of opening a new chapter in the European populist era. Another clear example of a gradual ascension in the support for the far-right populist movements is the result obtained by Geert Wilders`s Freedom Party (PVV) in Netherlands. In an important test for the populist right-wing in Europe, the Dutch parliamentary elections in 2017, the victory went to pro-European Prime-Minister Mark Rutte, a result described as an opposition of the Dutch society in front of the "wrong kind of populism" (Said-Moorhouse 2017). The fact that PVV occupied the second place, illustrates important changes in the Dutch society's perceptions. This is a dynamic that needs to be accurately investigated in order to understand the 
importance of the main direction of Europe and of its system of beliefs and principles, after the French presidential vote in May and the German national election in September. In France, the presidential elections are not only a choice between candidates but a choice between two extremely different alternatives for the nation`s future: Marine Le Pen has already made it to the second round runoff in the presidential elections, and again, it is important to underline what are the elements that have drawn an important number of French citizens to support her political agenda.

The populist rhetoric growing attractiveness may be due to apparent political failures of the traditional established political elites, constructing a legitimate emotional backlash against the amplifying disenfranchisement perception of European citizens: "the European Union's compromise machine is perceived as an institutionalized grand coalition between the centre-left and the centre-right that routinely ignores opposing voices" (Broning 2016). European far-right populist parties have capitalized on the economic, political, ethno-nationalist frustrations in a move to transform public opinion support in real effective political power (Robins-Early 2017). The existent literature on populism supports the idea that neo-liberalism has hidden the language of strong debate behind the curtains of political correctness, and that this way "it not only obstructed democratic channels of expression for diverse political stances, but also delegitimized them".(Zabala 2017) Farright populist parties in Europe are promoting a particular understanding of politics aptly using citizens' frustrations and disenchantment in order to mobilize them to protest and revolt against the traditional status quo. Such a dynamic of manipulating feelings of fear, insecurity, is usually obtained by portraying the existent political system as a common enemy.

In the effort of explaining the recent growth of support for far right-wing populism in Europe, this paper builds on the important theoretical contributions of scholars such as Cas Mudde, Michael Minkenberg, Hans-Georg Betz, Ronald Inglehart and Pipa Norris, Pierro Ignazi etc. Up to this moment, there is no universally accepted and used definition of populism. Cas Mudde believes populism represents that: "thin-centered ideology that society considers to be ultimately separated into two homogenous and antagonistic groups, "the pure people "versus" the corrupt elite" and which argues that politics should be an expression of the 
general will of the people." (Mudde and Kaltwasser 2011, 5). Mudde created this definition starting from three features of populist movements: anti-establishment feelings (strong opposition towards the traditional parties and the results of their proposed governmental programs), authoritarism (the manner in which the concept of leadership at the party level is centered on the existence of a single leader who coordinates and represents the entire image of the party) and nativism (primacy of national interest in what regards the interaction with supranational structures or foreign entities) (Inglehart and Norris 2016, 7). According to Laclau and Mouffe, cited in Santiago Zabala`s article, populism should not be considered an ideology but rather a "political form capable of articulating identities, interests, and needs that have been delegitimized by centre-right and centre-left parties"(Zabala).

Tjitske Akkerman expanded this perspective and considered that there are three possible ways of conceptualizing populism (Akkerman 2003, 148). A niche perspective is one that puts a sign of equality between populism and new radical right-wing parties, but this is not an accurate perception because new parties are not implicitly populist but rather rightist. In Akkerman`s opinion, populism "is not primarily about style, it is neither primarily about immigration and multiculturalism. Populism is first and foremost about the perceived degeneration of representative democracy"(Akkerman 2003, 149). A second perspective argues that populism does not need to refer exclusively to the new right parties, but also to vested parties, thus talking about a respectable populism that distinguishes itself from the radical right populism due to its constitutionalism feature - respectable populism does not represent a threat to a society`s constitutionalism. Finally, Akkerman considers that populism can be understood as an incomplete ideology, a movement that has not received important intellectual recognition. Populism as an ideology in a strict sense does not exist, but populism manipulates important concepts in its rhetoric: popular sovereignty; an essential accent on popular opinion - the moral corruption of traditional political elites is appreciated as the main problem of representation; a cultural notion, a romantic and collectivist view of the people - evoking history, heartland and appealing to emotions (Akkerman 2003, 150-151). 
Another conceptualization of populism was proposed by Herbert Kitschelt who appreciates populism as "an expression of dissatisfaction with existing modes of organized elite-mass political intermediation and the desire to abandon the intermediaries that stand between citizens and rulers" (Kitschelt 2003, 179-196, 179). The author proposes understanding populism according to the next coordinates: the current society is split into two categories, numerically disproportionately represented. On one side we find the traditional political elites, few in number, who hold the levers of influence and control, and on the other side lie the masses, the "ordinary people", whose needs and wishes are apparently not taken into account by their rulers. In this context, populist parties ask for the vote of the people, using two main arguments: 1 . the need for a strong limitation in the influence of the selfless corrupted political class; 2 . the need for decreasing the distance between society's aspirations and needs and the political will of the decision-making leaders to accomplish them.

Carlos de la Torre argued that populism can also be understood as a "rhetoric that constructs politics as the moral and ethical struggle between el pueblo and the oligarchy" (Torre 2000). In a recent article, The Economist titrated: "Europe has a dissonant new voice. Anti-Muslim, anti-elite, anti-globalization and increasingly anti-Brussels, populist now count for something (...) they come in many varieties" (The Economist 2011). This statement of the British newspaper underlines the difficulty of defining the populist phenomenon. To overcome this important concept defining dilemma, the European Humanist Federation offers an approach that gives populism a definition based on its general features (European Humanist Federation 2013, 1):

- populist movements argue that only they can instate and sustain a direct, true democracy, blaming at the same time through their manichaeistic rhetoric the political system as strongly faulty, corrupt. An example here is the statement of Frauke Petry (Alternative for Germany, AfD) who claimed that "there is no other patriotic parties in Germany except for AfD" (Politico 2017);

- parties that adopt a populist speech describe themselves as offering immediate, efficient solutions to citizen`s everyday problems. In many Western European communities the fear of terrorist attacks is persistent along with an increase in an anti-Islam, racist radical wing rhetoric. To 
diminish the feeling of insecurity blamed on the immigrants, especially on the European Muslim communities, Geert Wilders has offered a fast and efficient, from his point of view, solution: "Muslims should simply go; we should treat them as Communists during the Cold War" (Traub 2017). This approach of managing the immigration issue is also reflected at the level of AfD leaders who stated that "applicants for asylum who are illegally in Germany should be taken to several islands outside of the European Union, under the mandate of the United Nations" (Delker 2016);

- in their speech, populist leaders use terms such as nation, sovereignty, us, corrupt elites. The Nation, simplistic defined as "we" is placed in the centre of every public position and statement, its history is glorified, creating an image of superiority in front of the others/foreigners appreciated as inferiors. Current difficult issues such as unemployment, crime, violence, economic and social instability are portrayed as the direct result of the others in a strongly manichaeistic rhetoric;

- for populist movements, the Nation and community traditions are idealized, while any form of supra-state organization is perceived as a threat. On the occasion of the Congress of European Nationalist MEP, organized at Sinaia, Romania, 2016, Marine Le Pen said that "at present, the EU is an enemy of freedom, an opponent of Nations' sovereignty and even an opponent of democracy" (Digi24 2016);

- populist movements have a strong position vis-à-vis the globalization phenomenon and promote social programs designed to support the needs of those social groups and populations appreciated to have been affected by globalization.

All these approaches converge towards the same idea, that populism is built on the perception that there is a conflict inside the society between two groups: a group of those moral, many people and a malicious elite that uses every opportunity of globalization for its own benefit. This perception offers populists the ability to add a moral dimension to every topic addressed in the public sphere (Hawkins 2009).

Regarding the notion of far-right party, the theoretical approaches are numerous and diverse. In the relevant published literature there are many terms to refer to 
far-right parties: new populism (Betz and Immerfall 1998), radical right-wing populism (Helms 1994) or the new right (Minkenberg 1997). In an article published for the London School of Economics, Othon Anastasakis $(2000,6)$ proposed grouping far-right parties on the basis of some general characteristics in a unitary approach. The author considered that an assessment of the literature on this subject enables the identification of four dimensions that can be found with a predilection in a far-right party`s essence: a far-right historical dimension (parties that are trying to bring back the era of fascism, the fascist legacy being a significant variable and perennial issue - "scholars have tried to stress the historical continuity of that trend of political thought and behaviour, and attempted to define the political and ideological space of contemporary extremism" Anastasakis 2000, 6); a structural dimension (parties that appear as a result of the negative consequences of globalization, post-industrialism, immigration, unemployment, being widely known that people tend to adopt right wing views in times of economic recession and of growing inequalities); a political dimension (far right parties pretend to be in the position of "political protesters", portraying themselves as the alternative force that can fight corruption and patronage, thus using the perceived climate of disaffection, distrust and alienation of some individuals and the weakening of traditional voter loyalties in order to implement their particular strategies); $a$ cultural ideological dimension (parties that adopt a xenophobic attitude, using notions of ultra-nationalism, hatred towards immigrants, but important to remember is that "it is in the rejection of cultural pluralism of the liberal political system, the reaction to the system's tolerance towards national minorities and the adoption of an exclusionary perception of citizenship, where lies the ideological essence of right wing extremism") (Anastasakis 2000, 16).

\section{THE RISE OF FAR-RIGHT POPULIST PARTIES IN EUROPE}

A common view in the published literature on far-right populism, is that the modern globalized, dynamic times we live in, have deeply transformed Western societies so that the dominant approach is no longer one that puts equity and social solidarity on a first pillar, but one in which competition and individualism 
have gained importance. The increase in the influence of populist parties is sometimes attributed to the negative effects of globalization. From the perspective of "the many", the elites are the ones who benefit the most from globalization and modernity, the majority of Western individuals feeling "vulnerable and defeated", while simultaneously experimenting an increasing lack of self-esteem (Guibernau 2010, 5). For many social categories, the globalization process has brought a level of economic insecurity/ need for fast adaptation to a new world that permanently changes (Guibernau 2010, 7).

This vulnerability is also reinforced by the widespread perception that immigrants are benefiting from undue support from the host State and that they "steal" too many jobs that normally were attributed to those perceived as "natives". Some foreigners from certain immigrant minorities, especially Muslims are regarded as ",aliens", a dynamic that fosters fear, lack of trust, open hostility, that in time, transforms into xenophobia and racism. The perception of economic insecurity, combined with the idea that "foreigners are stealing our jobs and trying to change our way of life" has paved the way for an increase in the influence of populist parties.

Another theory is that proposed by Piero Ignazi which elaborated the following explanation for understanding the increase in the influence of populist parties. The inability of mainstream political parties to meet the expectations of the voters has created spaces (power voids) that were occupied by social movements, which later became policy oriented groups, and in the end, political parties. (Ignazi 1996) Populist parties manage to win support ,due to voters' dissatisfaction with government policies on issues such as immigration and crime and, at a more profound level, due to growing uneasiness in the plural, conflicting, multicultural and globalizing society" (Ignazi 2003, 217).

The rise of populist parties is also determined by the mediatisation of main far right leaders. In modern days, mass media plays a huge role in pushing diverse socio-political agendas. A good example is that during The Great Depression in the United States, Reverend Charles Coughlin, anti-Semitic supporter of fascism promoted an anti-elitist (anti-Wall Street/anti-bankers) view, a view which in a very short period of time managed to obtain 40 million listeners, mostly working class, white ethnic immigrants (Burack and Snyder-Hall 2012, 446). 
In an attempt to explain the rise of far right populism in Europe, initiatives have focused on designing such a voter portrait, but in many cases this has resulted in a classist cliché profile. For example, in his paper, professor Matthew Goodwin (Chatham House) considers that populist parties voters are mainly individuals that are strongly pessimistic about their economic prospects and opportunities, that feel economically insecure, more specifically ",men, very young or elderly, without or with a few educational qualifications, who come from the petite bourgeoisie and the working classes, from voters that are less educated than the average voter" (Goodwin 2011, 6). Regarding young people that adhere to a far-right populist party`s agenda, the main explanation is that because they are in the process of forming their systems and structures of thought, beliefs and attitudes, they can sometimes, easily be influenced by the strong mediatisation of populist rhetoric. One third of the British young people, aged 18 - 24, acknowledged that their Brexit vote will have been influenced by social media (The Guardian 2015). In Goodwin's opinion, the elderly respond with greater ease to a right-wing populist party`s message because they have a conservative attitude towards the liberal ideas promoted by EU Member States Governments.

Yet recent polls have shown that the above mentioned typology does not fully cover the entire range of voters for a populist party. For example, in France an analysis showed that the mass of voters is much more diversified: after the working class, we find skilled workers, farmers, freelancers, students, the professional class and even the managerial class (Chassany 2016). These information prove that there are general criteria that provide a perspective on the latest evolution of European populist parties, but in order to fully understand this phenomenon, it is important to comprehensively analyse European populist leader's public positions, statements and arguments on various topics of interest. In the next part of this paper, I will present and analyse the political programs of two main populist parties in Europe: Alternative for Germany (AfD) and The National Front (FN), regarding topics such as: immigration, national identity, sovereignty versus supranational authority, established traditional political structures. 


\subsection{ALTERNATIVE FOR GERMANY (AFD)}

The AfD movement gradually obtained political influence. In 2013, the publications that followed the German political scene, questioned the idea that the party was able to pass the 5\% threshold in order to enter the Bundestag (Freudenstein 2013), while other media sources appreciated that "Europe must not worry about a German anti-European government because AfD had no chance of entering the Bundestag" (Leinen 2013). After the elections from September 22th 2013, German publications stated that "Merkel avoided a bullet because AfD failed to enter the lower House of the Bundestag" (Leinen 2013). The 2016 elections from Mecklenburg - Vorpommern shocked many across Europe, the traditional Christian Democratic Party (CDU) placing third in the regional elections behind the AfD, a party recently founded. After only four years since its establishment, the party won seats in 10 of the 16 local German parliaments, and one of the most resounding victories was the result of Berlin elections where it obtained $14 \%$ of the votes, the best score made by a far-right party since the Second World War (Schwartz 2017).

Bernd Lucke, an economist and a founding member of AfD defined the main political-ideological agenda of the party as comprised of: shutting EU`s external borders to immigration, a strong anti-Islam platform, skepticism regarding EU supranational decision-making forum and promoting the traditionally conservative Christian social values (Knight 2016). On January 25th 2014, on the occasion of launching the campaign for the European elections, Lucke compared his party`s fight against the system with the battle of David against Goliath. He argued that "mainstream parties on the left and right were too "cowardly" to address Europe's conflicts and problems; we can only win if we stick together", blaming EU federalism proposals and defending German national sovereignty. (Timmann 2014) AfD leaders try to create a negative image for traditional political elites, by defining them as corrupt and lacking responsiveness, a 2016 opinion poll of AfD supporters concluding that they agree with the notion that the German traditional political establishment operates independently of their opinion (Amman et al. 2016). 
The upward trend of the populist party (Chase 2017) was fuelled by the political ideas promoted by AfD`s leaders, ideas that are reflected in their speech and that can be comprised in certain categories.

Firstly, AfD promotes a strong anti-immigration stance. The open gates policy initiated by Angela Merkel, through which more than 1 million refugees have entered Germany from 2015 and so far, has strengthened AfD`s antiimmigrationist rhetoric. This position against foreigners has been constructed by defining refugees as the main reason for all the problems the German society experiments, by a) inducing the ideea that immigrants and refugees alter German national identity; b) that they engage in illegal actions and thus generate strong social unrest; c) that they occupy jobs that normally were meant for German native citizens; d) that they aptly use the German social security net in order to obtain undeserved financial benefits (Rydgren 2008). AfD has attributed in its political and social program an essential place to traditional family values, German identity, language and culture, while multiculturalism and Islam are not tolerated as long as they are perceived as colliding with these fundamental principles and beliefs. This portretization of the refugees and immigrants in general is essential to AfD`s leaders speeches. The arguments exposed next are the result of analysing a large number of official statements posted on AfD`s website $^{1}$ (561 texts published between January 2016-April 2017), supporting and comprehensively explaining the anti-immigrationist views cited above.

\section{a) Perceptions on immigration}

The public discourse of AfD`s leadership mainly focuses on inducing the idea that the refugees crisis has turned Germany into a fortress under siege. AfD tries to portray German values, principles and beliefs as being threatened by refugees and immigrants and as I will further explain, in order to support its main thesis, AfD uses diverse arguments from economic forecasts to historical examples.

\footnotetext{
${ }^{1}$ AfD`s website is: https://www.alternativefuer.de/ .
} 
Most AfD voters opted for this party`s agenda due to its direct expression of a strong disagreement with the "open doors" policy promoted by Chancellor Angela Merkel. At present, the party's political program is built around the idea of "resistance" against the perceived exclusively negative implications of the refugees`crisis. In 2016, one rationale used to convince voters of the need to strengthen German borders was built on the idea that the readmission agreement with Turkey cannot be effective because of Turkish president Erdogan's behaviour unpredictability and because of his harsh rhetoric against the EU. Erdogan stated at that time that he could anytime flood Europe with refugees. Alexander Gauland (AfD member) strongly promoted the idea that the arrival of refugees in Germany, would instate a "madness which would again be at the expense of our (German) society" (Gauland 2016 a). Invoking the terrorist attacks in France and Belgium, Andre Poggenburg (leader in Saxony-Anhalt AfD) claimed that Europe should become a fortress to protect itself from the dangers of multiculturalism and islamization (Poggenburg 2017).

Concerning the connotations offered to the possible negative implications stemming from the crime acts considered to be generated by the presence of refugees, AfD leaders use a rhetoric that offers enough space for interpretation. In a post on the party`s webpage, Frauke Petry argued that "too many people are now feeling the fatal consequences of Merkel's "welcome guests" (Petry 2016 a). Specific references to cases of violence are presented in a manner that tries to reflect events in the history of Germany which strongly affected the national consciousness. For example, five days after the attack against some women in Cologne, Petry declared that the event was similar to the situation and conditions from World War II (Petry 2016 b).

The party's ability to convey the desired messages is enhanced through the use of powerful emotional impact statistics. In a paper, an AfD member stated that the number of immigration related offences increased by $79 \%$ in 2015 , so that he concluded that in Germany, nowadays, pepper spray as protection against immigrants and refugees is found in the bags of all women and girls (Hampel 2016). The article portrays German society as a community under permanent siege, imposed by refugees who engage or commit acts of violence. 
AfD believes that providing refugees with incentives (financial/easy access to the labour market) diminishes their desire for integration (Weiden 2016). By promoting this type of message, the Party tries to induce to the public opinion the idea that German citizens`access to the labour market is restricted because of the social programs aimed at the inclusion of refugees in the workforce. In AfD leaders'opinion, because any new immigrant, especially refugee coming from war zones is very difficult to integrate into German society, the majority of migrants get to unjustly benefit from the advantages offered by the German social system (Gauland 2016 b). Jörg Meuthen tackles the German welfare state idea from another angle and promotes the idea of eliminating part of the German social legislation in order to totally stop immigrants' access to social benefits: "only in this way can a welfare State continue to exist in the long term" (Meuthen 2016).

\section{b) Perceptions regarding national identity and traditional political elites}

AfD also plays the nationalism card in order to accomplish its goal of lessening the legitimacy of the European construction and of the current German political establishment. Next I will provide an analysis of AfD members'statements identified as designed to amplify the nationalist feelings at the expense of the liberal values promoted by the European Union.

In 1985, the President of Germany, Richard von Weizsäcker argued in a speech that the 1945 Allied victory should be regarded as "the liberation of the German people, not as their defeat" (Markham 1985). Populist, Björn Höcke (AfD) blamed that kind of pro-Western/ supranational appreciation attitude and considered von Weizsäcker` speech as a "speech against his own people, and not for his own people" (Taub and Fisher 2017 a). This type of hostile attitude towards the traditional German political establishment's approach has also resulted from the following statement: "establishment parties in addition to some other enemies are liquidating our beloved German fatherland, like a piece of soap under warm running water; Yet we, we beloved friends, patriots, we will close this open tap, in addition we will win back our Germany, piece by piece." (Taub and Fisher 2017 b). 
To justify the strong nationalist political approach as opposed to German traditional political establishment, in particular in relation to Angela Merkel, AfD`s leaders have manipulated the refugees crisis and transformed it, as seen above, into an essential topic of their rhetoric. In an article published in March 2016, AfD leaders stated that "Merkel is not capable of reaching a European solution and rather further divides Europe and isolates Germany in the community. This Chancellor has become a security risk for all of Europe" (Gauland 2016 c). AfD`s way of using the nationalism card is always supported by injustly connecting Islam to terrorism. For example, following the bombing of St. Petersburg, on April $3^{\text {ed }}$ 2017, the Presidency of the Russian Federation submitted a statement whereby it stated that Russian officials cannot rule on the reasons and mode of action of the attacker (Kremlin News) but on April 4th, one of AfD`s regional leaders, Andre Poggenburg, underlined that "AfD condemns the Islamic terrorist act in Saint Petersburg". This immediacy in defining the incident as one of Islamic origins, is vital to AfD`s political programme according to which "Islam does not belong in Germany" (The New York Times 2016).

These kind of official statements provide an insight into the way AfD tries to present itself in front of the German electorate, this type of public positioning exposing its entire "ideological reasoning", its founding principles and beliefs. The message for the German citizens is pretty simple: Germany has a problem as a result of the actions of the current political class and its total submission to supranational institutions as the EU, AfD is the only party comprising true German patriots who are aware of this problem and most important who are capable of solving it - AfD proposes itself as an alternative way of politics in Germany.

AfD strongly campaigns for decreasing EU`s influence and simultaneously for consolidating German national sovereignty, restoring what they perceive as the strong true German national state, while also proposing the elimination of the euro and the European Banking Union. Albert Gallegos (AfD) started from the argument that Germany's foreign debt grew since the 1960s from 1,000 Deutsche mark/inhabitant to 25,000 euros/person, and concluded that because in this fast pace, the euro-zone will face more difficulties and that Germany is going to pass through a new crisis, Germans should "be careful before it is not too late". (Glaser) 
To justify the necessity of recovering the sovereignty transferred to the European Union, AfD leaders comment on topics relating to European Central Bank's monetary policy: "the recent monetary policy decisions of the ECB show that their boss, Mario Draghi has finally lost every measure and his monetary policy compass, which he probably never had anyway " (Weidel 2016). This is a clear example of the direct criticism of AfD towards the ECB, but without an exact reference to the measures taken by Mario Draghi, or the real possible consequences, AfD leaders trying thus to create for the public opinion the idea that Germany will be the country most affected after the implementation of the European Bank's policies. Also, commenting about one of the bond purchasing programmes initiated by the ECB, Frauke Petry concluded that: "Draghi`s actions at the ECB would destroy in a few years what generations have built up after the Second World War" (Petry $2016 \mathrm{~d}$ ). In an online post, Frauke Petry stated that the main consequences of a Brexit will be transferring all the Union's financial weight on Germany`s shoulders. At the same time, Petry considered that regarding the official reporting to Brussels, London was the only European country able to draw alarm signals when the EU was heading towards some wrong decisions (Petry 2016 c).

Through this kind of political rhetoric and through its official statements and public standings, AfD is acting to strengthen its position as the only party in Germany that totally opposes all that Merkel and her establishment represent, promoting AfD as the only patriot political entity with a capacity of providing "objective solutions" (Petry 2016 e).

The entire evolution of the party since its establishment and until today attests to the existence of a real interest for the development of a comprehensive political platform, so as to extend the number of potential voters. On medium and long term, in developing future strategies, AfD will probably use the unstable geopolitical context from inside the European Union and the fragile regional and international setup in order to advance its goals. Originally, the European Coal and Steel Community, the European Economic Community and the European Community, the predecessor entities of the European Union were constructed on the basis of a strong belief in the need of accentuating the economic integration, based on the main four freedoms (free movement of goods, capital, services and people). All the steps undertaken in this regard have been accepted by Member 
States because they generated economic opportunities for their own citizens. Subsequently, the European Union has increasingly gained the essence of a strong political project, which would have not been possible without the common consent of each Member State to jointly exercise their sovereignty in the EU institutional forums. AfD promotes a different image in which Germany ceded an important part of its national sovereignty because of the political and financial obligations derived from its EU membership. The perceived cession of national sovereignty to a supranational forum represents the main element that enables populist parties like AfD to build political platforms focused on the need for restoring what they appreciate as lost sovereignty, for punishing traditional political elites and for bringing forward what they call the interest and the voice of the street.

\subsection{THE NATIONAL FRONT (FN)}

The National Front was born in a time when a number of French voices developed and interiorized the perception that their country was "threatened" by foreigners. In the early 1970s, French public opinion was involved in intense debates generated by the situation of some 400.000 young Algerians who were to receive French citizenship. At that time, the French people were split into two divergent sides, a situation determined by the diverse answers to the same question: "were those Algerians Frenchmen with the heart?" (Albertazzi and McDonnel 2008, 169).

FN`s 1985 political program defined the nation as "the community of language, interest, race, memories and culture where man blossoms. [A man] is attached to it by roots and deaths, its past, heredity and heritage. Everything that the nation transmits to him at birth already has an inestimable value" (Davies 1999). This definition outlines the way in which the National Front structures its perception on the world: the nation always takes precedence over individuals, the nation being essential for their life and development. If we take this definition and try to view the immigration problem, it can be observed that behind these words there exists an important rejection perception and opposition attitude towards foreign political, 
economic, cultural values, considered a threat to French national identity. All foreign, external values and principles are considered capable of affecting the vital communion French nation- French citizen and of destroying the nation-state legacy that the FN elevates to a sacredness rank.

Trump's victory in the presidential elections of the United States represented a strong impulse for all populist movements in Europe. The results were discussed by vice Chairman of the National Front, Florian Philippot on Twitter: "their world is collapsing, ours is being built"(Lowe et al. 2016). To better understand the National Front's political approach regarding the current dynamics in France and Europe, I selectively analysed public speeches available on the party`s website and I identified numerous directions of political thought, the main values and beliefs that underlie the ideology of the National Front.

\section{a) Perceptions on globalization}

Since 2011, FN`s messages were focused on the need of reevaluating the traditional European political mindset that promoted the importance of globalization and the necessity of eliminating trade/territorial barriers. To demonstrate the importance of the idea of a closed border French state for FN, its leader, Marine Le Pen appeals to economic arguments: the diminishing number of jobs for French citizens, the decrease in French industrial productivity and of its GDP. Le Pen claimed in numerous press releases that every billion possibly spent by France on helping a European country in case of a major bailout represents nothing but a major loss for French citizens. In this context, FN's leader promoted the idea of regaining total control over the economy by the French Government ("France must free itself from the guardianship of the markets"Marine Le Pen 2011 a). This is a vital argument in FN`s political rhetoric, the party constantly emphasizing that French national policy is subjugated to the interests of international financial institutions, and blaming the current political establishment for not being capable of generating effective solutions to the economic crisis. 


\section{b) Perceptions about the traditional French political establishment}

FN leaders present the party`s role in similar terms with AfD`s own self-defining statements. FN`s political mission acquires "sacred" meanings because it portrays current French political architecture as a battle between good and evil, a struggle in which FN is described as the only actor truly fighting for France and for the French people: "in this struggle we are fighting for France" (Marine Le Pen 2011 b) The importance of the party and its leader presented as an alternative to the traditional French political establishment, is underlined by the statement "the French can count on me" (Marine le Pen 2011 c). FN`s leader has constantly tried to present the party as a socio-political movement able to represent the hope and revenge the wrath of the French people, a good example being the Le Pen's speech announcing her candidacy at the presidential elections in 2012: "my candidacy for the presidential elections shows the way to France and the French people (...) to give it back the pride, the honor, the love in the world" (Marine Le Pen $2011 \mathrm{~d}$ ). On the other side, the main parties of the French political spectrum are portrayed as entities acting in contrast with the interests of French citizens: "arrangements are made between oligarchs, far from the voters eyes, by dividing their roles and assuming in advance the share of the cake" (Marine le Pen 2011 e).

There is also a tendency to present the results obtained by the party in various elections (local, regional) as systemic shocks at the level of the French political spectrum, capable of generating fear among Government politicians. The identified examples illustrate that this kind of statements and public political positioning are built according to FN`s strategy on two coordinates: 1. the positive results of the party in various elections are constantly intensifying, meaning that FN is gradually becoming an important force on the French political scene and that such a posture must be respected by the establishment politicians; 2 . the party's political platform and the changes that it might induce in the event of a major electoral success would produce systemic changes in France.

In this context, Marine le Pen amplified the party`s political rhetoric in order to induce the idea of a growing legitimacy in front of the French people: "the French have begun to believe in us again. We gradually improved our electoral results in the 
regional elections. Our performance has made the whole system tremble, and I can tell you, it has not finished shaking" (Marine Le Pen $2011 \mathrm{f}$ ).

\section{c) Perceptions about the European Union. The Paris-Sovereignty- Brussels Trinom}

FN`s approach toward the concept of French national sovereignty is built into its rhetoric through a mechanism of argumentation composed of several steps:

1. underlining the importance of sovereignty which is presented in an objective manner as the freedom of a State to enforce its own laws and rules;

2. underlining the constraints imposed by EU`s decision-making mechanisms on national parliaments, obliging them to transpose into law Brussels legal directives;

3. underlining that the laws issued by the European Union do not represent the will of the people, but of a supra-state entity ("the parliamentary herd is only following the paths his master wants to point out" - Marine le Pen $2011 \mathrm{~g}$ ).

This manner of rhetoric elaboration offers FN leaders the ability to issue an essential conclusion: the European Union is a construction which weakens the French people and reduces the rights of French citizens.

The sovereignty of France is one of the concepts which is most diversely approached in Le Pen's speeches. The glorification of the French nation reinforces and projects for $\mathrm{FN}$ the image of a party that places the national interests of France first. Speaking of herself, Marine Le Pen stated: “it was my deep love for our country and our people, the pride of being born, the consciousness of a magnificent history of France, of greatness and grief, the boundless admiration for the genius of our people" (Marine Le Pen 2011 h). In order to obtain voters`support, FN utilizes powerful emotional resorts for every individual: love of country and criticism towards those who try in their opinion to destroy it, being unfitted to rule (those French government officials accused of acts of corruption, involved in media scandals). In the race for 2012 presidential elections, Marine Le Pen declared: "how can one love France when one accepts to empty French sovereignty of all 
its substance? When someone tries to impose on the people an ultra-liberal platform which hurts so badly, which constantly adds evil to evil?." (Marine le Pen 2011 i).

Compared with the AfD, the analysis of FN`s expressed public official positions, illustrates a trend toward a strong exploitation of the nationalist sentiment and the pride of being French. AfD constructs its messages and system of beliefs and thought starting from the fact that it portrays itself as the only entity capable of managing the political, economic and social dimensions of Germany`s society. AfD`s messages have a strong technical nature (the party uses statistics, forecasts, variations of action for a specific problematic). By way of comparison, FN uses at first in its rhetoric, concepts that are directed at the emotional side of the interlocutor, and only after that, in some situations their speeches seem to be also defined by pragmatic meanings.

\section{d) Perceptions about immigration}

Immigration represents one of the central topics in all FN leaders` speeches. In addressing this issue, the party uses statistics in a move meant to construct the perception that the increase in crime acts in France is directly proportional to the rising number of immigrants who have entered French territory and who, for various reasons were unable to integrate into the community.

Marine le Pen argued in a speech that the number of violences towards French citizens has increased by $45 \%$ from 2002 and continues in the opinion of FN`s leader "in the face of this surge of insecurity, largely due to the continued rise in immigration" (Marine le Pen 2011 j). This paper does not seek to identify the exact connection between immigrants and the crime rate in European societies, but merely to examine and present the manner in which far right populist parties as FN instrumentalize various topics of interest of a community (immigration, refugees' crisis) in order to attract supporters and obtain votes.

On January 1, 2014, the party adopted a petition entitled "Romania, Bulgaria: the total opening of borders after January 1st - total madness!" (Front National Petition 2014), where they described EU's decision to open up some Member States borders so that Romanians and Bulgarians could enter more easily the labour market, as an aberration in times of full economic crisis defined by high rates of 
unemployment. Another petition, "Against the European Charter and the balkanization of France, let us sign for national unity!", FN`s leaders tried to inoculate by title and content the idea that France is under violent siege, and that only the National Front "will truly fight for national unity, for France (...) The French are invincible!". (Front National)

The political programme and public rhetoric exposed and promoted by Marine Le Pen illustrate the party`s stylized, romanticized image of the French nation, created by using strong statements with important emotional and historical weight considered capable of generating reactions at the level of most French citizens.

\section{CONCLUSIONS}

From the analysis of the two far right populist parties from France and Germany, parties that have managed to obtain important positions and to monopolize at different times the media attention, some important conclusions can be drawn. Thus, irrespective of the fact that some differences exist depending on national specific factors such as political history, culture, society values, there have been identified important similarities.

In the first place, the two analysed far-right populist parties have extensively used a classic dichotomist narrative "us versus them", by positioning the party as the only true political entity that can represent the authentic voice of the people andthe traditional political structure defined as corrupt and illegitimate. In this context, they aptly manipulate and promote two main ideas: that the traditional political parties are controlled by corrupt leaders that lack will or capability to support the interests of "the many"; and that their own political creation, be it Alternative for Germany or the National Front, represents the only ally of the community, of those people who go out into the streets to protest ("we are the natural ally of people going out on the street demonstrating" (Sebastian 2016).

These parties use specific types of rhetoric and messages in order to attract public opinion`s interest, to shock, to make the people strongly debate on the 
proposed topics, to convince them that their party is composed of passionate politicians who are truly interested in all political, economic or social aspects of their daily life. A set of emails leaked by Vice News containing the correspondence of AfD`s leader, Frauke Petry, tends to confirm this mechanism of capturing public opinion`s attention: "pointed and sometimes provocative statements are imperative to get us a hearing in the media, to get us the necessary attention" (Sebastian 2016).

Secondly, in order to attract voters' support, these populist parties have developed and fuelled another important narrative - us versus them - regarding the immigration policies. Far right populist parties juxtapose European nations identity, values and culture to the identity, values and culture of the ones perceived as foreigners, the others, considered unjustly favoured by the corrupt elites. What is important to remember is that "the more ethno-centric the conception of the people, the more xenophobic the positioning against »the other " and the clearer the desire to overthrow the democratic system of governance, the more likely it is that a rightwing populist party is also extremist" (Greven 2016).

The terrorist attacks that occurred on European soil like London, Paris, Nice, Berlin, Brussels were for the first time carried out by European citizens, immigrants of second/third generation or even European converts to Islam, who embraced a salafi jihadist interpretation of Islam. These facts represent the main foundation on which today's far right populist leaders have built their strong anti-immigrant, anti-Islam, xenophobic and racist arguments. The strong antiimmigration approach seen in both populist parties' political agenda is reinforced by and it obtains its attractivity through the typical far right process of using negativity in political communication, and by surpassing the traditional political correctness dominant discourse. In this way, populist parties challenge the people to dare and debate previously considered taboo subjects, and allow feelings of frustration, indignation to find a new legitimately expression in scandals, protests and revolt.

Thirdly, the analysed populist movements pretend to be the sole "guardians" of nationalism. Far-right populist parties try to weaken the European Union and diminish the European institutions legitimacy. Even though populist leaders may appreciate the opportunities created by globalization, they argue that the 
side effects of evolutions such as market liberalization and opening of borders negatively influences the spirit and national identity. For this reason, the EU is rhetorically constructed by these two far right populist parties as an entity that only imposes rules. In this manner of perceiving reality, far right populist parties present the jointly agreed exercise of European States national sovereignty in the EU institutional forums, as a cession of sovereignty to Brussels. This process is perceived as being followed by a gradual erosion of the national traditional values European states like France or Germany are built on. Also from an economic point of view, populist parties consider that the benefits of such an adherence and "submission" in front of supranational forums and entities are much smaller than the costs that each French of German citizen must pay.

By promoting an exclusionist approach towards immigrants they fuel strongly anti-democratic feelings and attitudes. Both AfD and The National Front promote far-right populist messages that tend to deepen society`s socio-cultural cleavages and implicitly fuel xenophobic, racist and islamophobic attitudes. These political actors try to create the impression of European societies as being under constant siege in order to induce the perception of a permanently state of tension/fear to which only they, as the hero political entity can offer a real alternative.

By trying to present themselves as the "one true voice of the people", far-right populist parties threaten the institutions, values and principles that the European Union was built on. The European Union, helped through the solidarity and unitary voice of its Member States, has to undertake serious efforts to relegitimize all decisions to its constituents, to strongly promote and respect citizen`s participation in order to achieve a more input-oriented legitimacy (Scharpf 1999, 7). If the EU desires to maintain its superiority among other types of political structures, then democracy needs to return to the people and to their real needs. Traditional European parties need to understand and truly interiorize their role in the far-right populist ascension, they need to strongly critic all racist and xenophobic attitudes promoted by far-right parties, to formulate a coherent unitary response so that people will gradually stop perceiving far-right populism as the only entity capable of voicing their frustration and disillusionment. 
Europe is at a critical moment in its evolution and I do believe that it is extremely important to understand that European traditional political structures need to respond in a meaningful, tangible and real way to all the promises of the farright parties that threaten the very essence of the European continent, its democracy and values. In this process of combating the constant promoted repudiation of liberalism, solidarity, integration and cooperation in favor of a narrow-minded catastrophic nationalism, European citizens must have the power to reject the politics of fear, division and nationalism, a process in which also European leaders must not forget that as Mark Twain said "history doesn't repeat itself, but it does rhyme".

\section{REFERENCES:}

- "The European Union and the Challenge of Extremism and Populism", European Humanist Federation, 2013;

- $\quad$ Albertazzi, Daniele; Duncan McDonnel (Eds.). Twenty-First Century Populism. The Spectre of Western European Democracy. Palgrave Macmillan, 2008;

- Anastasakis, Othon. "Extreme right in Europe: A Comparative Study of Recent Trends", London School of Economics, Discussion Paper No. 3, 2000;

- Betz, Hans-Georg; Srefan Immerfall. The New Politics of the Right: Neo-Populist Parties and Movements in Established Democracies, Palgrave Macmillan Press, 1998;

- $\quad$ Brent, Roberts. "Patterns of mean-level change in personality traits across the life course: a meta-analysis of longitudinal studies", Psychological Bulletin, Vol. 132 (1), pp. 125, 2006;

- Bryder, Tom. "Populism a threat or a challenge for the democratic system?", University of Copenhagen - Department of Political Sciences, 2009;

- $\quad$ Burack, Cynthia; R. Claire Snyder-Hall. „Introduction: Right-Wing Populism and the Media", New Political Science, Vol. 34, Issue 4, pp. 439-454, 2012;

- Davies, Peter. The National Front in France: Ideology, Discourse and Power, London: Routledge, 1999;

- De la Torre, Carlos. "Populist Seduction in Latin America: The Ecuadorian Experience", Foreign Affairs, Vol. 74, Issue 4, 2000;

- $\quad$ Goodwin, Matthew. “ Right Response: Understanding and Countering Populist Extremism in Europe", Chatham House Report, 2011;

- $\quad$ Greven, Thomas. "The rise of Right-wing Populism in Europe and the United States: A comparative perspective", Friedrich Ebert Stiftung, 2016; 
- Guibernau, Montserrat. "Migration and the rise of the radical right. Social malaise and the failure of mainstream politics", Policy Network Paper, 2010;

- Hawkins, Kirk. "Is Chavez populist? Measuring populist discourse in comparative perspective", Comparative Political Studies, 42, 2009;

- Ignazi, Piero. "The crisis parties and the rise of new political parties", Party Politics, Vol. 2, Issue 4, 1996;

- $\quad$ Ignazi, Piero. Extreme Right Parties in Western Europe, Oxford University, 2003;

- Inglehart, Ronald; Pippa Norris. "Trump, Brexit and the Rise of Populism: Economic Have-Nots and Cultural Backlash", Harvard Kennedy School, Faculty Research Working Paper Series, 2016;

- $\quad$ Kitschelt, Herbert. "Popular Dissatisfaction with Democracy: Populism and Party Systems in Democracies and the Populist Challenge, Yves Meny et al. (Eds), Palgrave Macmillan, 2002;

- Minkenberg, Michael. "The new right in France and Germany: Nouvelle Droite, Neue Rechte and the New Right Radical Parties", in The Revival of Right-wing Extremism in the Nineties, Peter H. Merkl and Leonard Weinberg (Eds.), London: Frank Cass, 1997, pp. 65-90;

- $\quad$ Mudde, Cas; Cristobal Rovira Kaltwasser. "Voices of the Peoples: Populism in Europe and Latin America Compared", Kelogg Institute for International Relations, Working Paper, 378, 2011;

- Scharpf, Fritz W. "Governing in Europe: Effective and democratic?", Oxford University Press, 1999;

- $\quad$ Tjitske, Akkerman, "Populism and democracy: challenge or pathology?", University of Amsterdam, Acta Politica, 2003;

- 10 things you need to know about the AfD", Deutsche Welle, 2017, available: http:/ / www.dw.com/en/10-things-you-need-to-know-about-the-afd/a-37208199 accessed 14.04.2017;

- "A third of young people think social media will influence their vote", The Guardian, 2015, available: https://www.theguardian.com/news/datablog/2015/mar/10/a-third-of-young-peoplethink-social-media-will-influence-their-vote accessed 10.04.2017;

- "Alice Weidel: Nein zu staatlichen Wettbewerbsverzerrungen zulasten von Arbeitnehmern", AfD, 2016, available: https://www.alternativefuer.de/alice-weidel-neinzu-staatlichen-wettbewerbsverzerrungen-zulasten-von-arbeitnehmern/ accessed 20.04.2017;

- "André Poggenburg: Wir brauchen eine Festung Europa, das MerkelWillkommenskartell muss weg!", AfD, 2017, available: https://www.alternativefuer.de/andre-poggenburg-wir-brauchen-eine-festung-europadas-merkel-willkommenskartell-muss-weg/ accessed 05.04.2017;

- "Beyond the fringe", The Economist, 2011, available: http://www.economist.com/node/21536873 accessed 20.04.2017; 
- $\quad$ "Contre la charte Européenne et la balkanisation de la France, signons pour l'unité nationale!", National Front, 2012, available: http:/ / www.frontnational.com/contrela-charte-europeenne-et-la-balkanisation-de-la-france-signons-pour-lunite-nationale/ accessed 12.04.2017;

- $\quad$ "Dutch election: Europe's far-right populists fail first test", BBC, 2017, available: http:/ / edition.cnn.com/2017/03/16/europe/netherlands-dutch-results/ accessed 20.04.2017;

- $\quad$ "Europa | Euro", AfD, 2017, available: https://www.alternativefuer.de/euroeuropa-2/ accessed 05.04.2017;

- $\quad$ "Europe's Rising Far Right: A Guide to the Most Prominent Parties", New York Times, 2016, available:

https://www.nytimes.com/interactive/2016/world/europe/europe-far-right-politicalparties-listy.html?_r=1 accessed 25.04.2017;

- "Gauland: Sichere Grenzen, statt Türkei als Türsteher", AfD, 2016 a, available: https:/ / www.alternativefuer.de/gauland-sichere-grenzen-statt-tuerkei-als-tuersteher/ accessed 21.04.2017;

- “Gauland: Zuwanderung geht zulasten der Schwächsten in Deutschland", AfD, 2016 b, available: https://www.alternativefuer.de/gauland-zuwanderung-geht-zulastender-schwaechsten-in-deutschland/ accessed 20.04.217;

- "Gauland: Merkel ist zum Sicherheitsrisiko für ganz Europa geworden", AfD, 2016 c, available: https://www.alternativefuer.de/gauland-merkel-ist-zumsicherheitsrisiko-fuer-ganz-europa-geworden/ accessed 20.04.2017;

- "Glaser: Die Staatskrise rückt näher", $A f D$, 2016, available: https://www.alternativefuer.de/glaser-die-staatskrise-rueckt-naeher/ accessed 25.04.2017;

- $\quad$ "Hampel: Der Politik fehlt der Mut zur Aufklärung - aber Hauptsache, die Statistik stimmt", AfD, 2016, available: https://www.alternativefuer.de/hampel-derpolitik-fehlt-der-mut-zur-aufklaerung-aber-hauptsache-die-statistik-stimmt/ accessed 20.04.2017;

- "Inside the revolt against Angela Merkel", Spiegel Online, 2016, available: http:/ / www.spiegel.de/international/germany/success-of-afd-populists-akin-to-revoltagainst-merkel-a-1083147.html accessed 18.04.2017;

- "Kultur | Sprache | Identität", AfD, 2017, available: https:/ / www.alternativefuer.de/kultur-sprache-identitaet/ accessed 18.04.2017;

- Marine Le Pen: Doresc să aplicăm şi noi actuala procedură din Marea Britanie. Francezii au dreptul să-şi spună părerea despre UE prin referendum", Digi24, 2016, available: http://www.digi24.ro/stiri/externe/ue/exclusiv-marine-le-pen-doresc-saaplicam-si-noi-actuala-procedura-din-marea-britanie-francezii-au-dreptul-sa-si-spunaparerea-despre-ue-prin-referendum-507882 accessed 17.04.2017; 
- "Meuthen: Der Deutsche Städte- und Gemeindebund hat recht", AfD, 2016, available: https://www.alternativefuer.de/meuthen-der-deutsche-staedte-undgemeindebund-hat-recht/ accessed 20.04.2017;

- $\quad$ Petry, Frauke. "Asylkompromiss ist ein faules Wahlkampfmanöver", AfD, 2016 a, available: https://www.alternativefuer.de/petry-asylkompromiss-ist-ein-fauleswahlkampfmanoever/ accessed 20.04.2017;

- Petry, Frauke. "Massenhafter Missbrauch von Frauen in Köln erinnert an rechtlose Zustände zum Kriegsende", AfD, 2016 b, available: https:/ / www.alternativefuer.de/ petry-massenhafter-missbrauch-von-frauen-in-koelnerinnert-an-rechtlose-zustaende-zum-kriegsende/ accessed 20.04.2017;

- Petry, Frauke. "Ein „Brexit" wäre fatal”, AfD, 2016 c, available: https:/ / www.alternativefuer.de/petry-ein-brexit-waere-fatal/ accessed 05.04.217;

- $\quad$ Petry, Frauke. "EZB-Politik ist falsch, schädlich und wirkungslos", AfD, 2016 d, available: https://www.alternativefuer.de/meuthen-ezb-politik-ist-falsch-schaedlichund-wirkungslos-petry-draghis-politik-ruiniert-banken-sparguthaben-und-staatengleichermassen-wer-haelt-ihn-auf/ accessed 21.04.2017;

- Petry, Frauke. "Pure Verzweiflung in der Großen Koalition", AfD, 2016 e, available: https://www.alternativefuer.de/petry-pure-verzweiflung-in-der-grossenkoalition/ accessed 20.04.2017;

- $\quad$ "Roumanie, Bulgarie: l'ouverture totale des frontières depuis le 1er janvier est une folie! Signez la pétition", National Front, 2014, available: http:/ / www.frontnational.com/2014/01/ouverture-totale-du-marche-du-travail-auxroumains-et-aux-bulgares-une-aberration/ accessed 01.04.2017;

- "Transcript: Tim Sebastian interviews Frauke Petry", Deutsche Welle, 2016, available: http://www.dw.com/en/transcript-tim-sebastian-interviews-frauke-petry/a19152089 accessed 20.04.2017;

- "Weidel: Der EZB Einhalt gebieten", AfD, 2016, available: https://www.alternativefuer.de/weidel-der-ezb-einhalt-gebieten/ accessed 06.04.2017;

- $\quad$ accessed 23.04.2017;

- Bradley, Matt. "Europe's Far-Right Enjoys Backing from Russia's Putin", NBC News, 2017, available: http://www.nbcnews.com/news/world/europe-s-far-rightenjoys-backing-russia-s-putin-n718926 accessed 20.04.2017;

- Broning, Michael. "The Rise of Populism in Europe", Foreign Affairs, 2016, available: https://www.foreignaffairs.com/articles/europe/2016-06-03/rise-populismeurope accessed 18.04.2017;

- Chassany, Anne-Sylvaine. "How France`s National Front is winning workingclass voters" , Financial Times, available: https://www.ft.com/content/ad9502f4-809911e6-bc52-0c7211ef3198 accessed 20.04.2017;

- Delcker, Janosch. "Far-right leader: Germans should be able to defend themselves", Politico, 2016, available: http://www.politico.eu/article/far-right-leader- 
germans-should-be-able-to-defend-themselves-frauke-petry-counter-terrorism-attackviolence-alternative-for-germany-afd/ accessed 20.04.2017;

- $\quad$ Freudenstein, Roland. "The German election: What's in it for Europe?", EurActiv, 2013, available: http://www.euractiv.com/section/elections/opinion/the-germanelection-what-s-in-it-for-europe/

- Greven, Ludwig. "Männersache", Zeit, 2016, available: http:/ / www.zeit.de/politik/deutschland/2016-01/afd-pediga-warum-wenig-frauenmiitmachen accessed 17.04.2017;

- Knight, Ben. "What does the AfD stand for?", Deutsche Welle, 2016, available: http:/ / www.dw.com/en/what-does-the-afd-stand-for/a-19100127 accessed 20.04.2017;

- Le Pen, Marine. "Crise financière : la France doit retrouver sa liberté face aux marchés", National Front, 2011 a, available: http:/ / www.frontnational.com/2011/08/crise-financiere-la-france-doit-retrouver-saliberte-face-aux-marches/ accessed 20.04.2017;

- Le Pen, Marine. "Discours lors du Congrès de Tours des 15 et 16 janvier 2011", National Front, 2011 b, available: http:/ / www.frontnational.com/videos/congres-du-fn-atours-discours-d \% E2\% 80\%99investiture-de-marine-le-pen/ accessed 20.04.2017

- Le Pen, Marine. "Protections aux frontières : comment relancer l'industrie et l'emploi?", National Front, 2011 c, available: http:/ / www.frontnational.com/videos/protections-aux-frontieres-comment-relancer1\%E2\%80\%99industrie-et-1\%E2\%80\%99emploi/ accessed 20.04.2017;

- Le Pen, Marine. "Colloque sur la defense", National Front, 2011 d, available: http:/ / www.frontnational.com/2011/12/colloque-sur-la-defense-discours-de-marine-lepen/ accessed 15.04.2017;

- $\quad$ Le Pen, Marine. “Conseil National du FN : Le discours de clôture de Marine Le Pen", National Front, 2011 e, available: http://www.frontnational.com/videos/conseilnational-du-fn-le-discours-de-cloture-de-marine-le-pen/ accessed 20.04.2017;

- $\quad$ Le Pen, Marine. "11 septembre / Acropolis de Nice", National Front, 2011 f, available: http://www.frontnational.com/videos/11-septembre-acropolis-nice\%E2\%80\%93-discours-de-marine-le-pen-videos / accessed 20.04.2017;

- Le Pen, Marine. "Discours du 1er mai 2011", National Front, 2011 g, available: http:/ / www.frontnational.com/videos/discours-du-1er-mai-2011/ accessed 12.04.2017;

- $\quad$ Le Pen, Marine. "Discours à Paris à l'occasion de la présentation de son Projet Présidentiel", National Front, 2011 h, available: http:/ / www.frontnational.com/videos/presentation-du-projet-presidentiel-de-marinele-pen/ accessed 11.04.2017;

- Le Pen, Marine. "Meeting à Metz : Discours de clôture de Marine Le Pen", National Front, 2011 i, available: http://www.frontnational.com/videos/meeting-a-metzdiscours-de-cloture-de-marine-le-pen/ accessed 24.05.2017; 
- Le Pen, Marine. "Marine Le Pen au Salon des Forrains à Pontoise", National Front, 2011 j, available: http://www.frontnational.com/videos/marine-le-pen-au-salon-desforrains-a-pontoise/, accessed 03.04.2017;

- $\quad$ Leinen Joe. "Germany must rethink its strategy as it cannot remain healthy amid a sick Europe", EurActiv, 2013, available: http:/ / www.euractiv.com/section/elections/opinion/germany-must-rethink-itsstrategy-as-it-cannot-remain-healthy-amid-a-sick-europe/ accessed 21.04.2017;

- Markham, James M. "Facing up to Germany's past", New York Times, 1985, available: http://www.nytimes.com/1985/06/23/magazine/facing-up-to-germany-spast.html?pagewanted=all accessed 20.04.2015;

- Matthews, Owen. "Why Europe's populist revolt is spreading", Newsweek, 2016, available: http://www.newsweek.com/2016/12/02/europe-right-wing-nationalismpopulist-revolt-trump-putin-524119.html accessed 06.04.2017;

- Robins-Early, Nick. "2017 Will test the rise of Europe`s Populist Far-Right", HuffingtonPost, 2017, available: http://www.huffingtonpost.com/entry/europepopulist-far-right_us_587561bce4b03c8a02d3ce90 accessed 20.04.2017;

- Schwartz, Yardena. "Meet Frauke Petry, the Donald Trump of Germany", Newsweek, 2017, available: http://www.newsweek.com/2017/03/17/frauke-petrygermany-afd-party-nationalism-564872.html accessed 17.04.2017;

- Sullivan, Patrick. "The Rise of European Far-Right Populism", Social Sciences Works, 2017, available:http://socialscienceworks.org/2017/02/the-wave-the-rise-ofeuropean-far-right-populism/ accessed 19.04.2017;

- Taub, Amanda; Max Fisher. “Germany's Extreme Right Challenges Guilt Over Nazi Past", New York Times, 2017 a, available: https:/ / www.nytimes.com/2017/01/18/world/europe/germany-afd-alternative-bjornhocke.html?_r=0 accessed 01.04.2017;

- Taub, Amanda; Max Fixher. “Far right leader stirs Germany`s long-suppressed nationalism", Bangkok Post, 2017, available: http:/ / www.pressreader.com/thailand/ bangkok-post/20170122/282918090167552 accessed 20.04.2017;

- Timmann, Patrick. “Germany's Eurosceptic AfD launches EU elections campaign", EurActiv, 2014, available: http://www.euractiv.com/section/eu-elections2014/news/germany-s-eurosceptic-afd-launches-eu-elections-campaign/_accessed 19.04.2017;

- Traub, James. "The Geert Wilders effect", Foreign Policy, 2017, available: http:/ / foreignpolicy.com/2017/03/13/the-geert-wilders-effect/ accessed 20.04.2017;

- Zabala, Santiago. "The difference between right and left-wing populism", AlJazeera, 2016, available: http:/ / www.aljazeera.com/indepth/opinion/2017/01/difference-left-wing-populism170112162814894.html, accessed 18.04.2017; 